\title{
Compositional Variations of Titanite: A Possible New Tool for Cyprus-Type Volcanogenic Massive Sulfide Deposit Prospecting
}

\author{
Gabriella B. Kiss ${ }^{1, *(1)}$ and Federica Zaccarini ${ }^{2}$ \\ 1 Department of Mineralogy, Eötvös Loránd University, Budapest Pázmány P. stny. 1/c, \\ 1117 Budapest, Hungary \\ 2 Department of Applied Geosciences and Geophysics, Montanuniversität Leoben, 8700 Leoben, Austria; \\ federica.zaccarini@unileoben.ac.at \\ * Correspondence: gabriella.b.kiss@ttk.elte.hu
}

Received: 30 June 2020; Accepted: 27 July 2020; Published: 29 July 2020

\begin{abstract}
Titanite in submarine mafic magmatic rocks of Neotethyan origin was studied to reveal its possible use as an indicator mineral of modern Cyprus-type VMS deposits. Four ore deposit bearing (mineralized) and eight barren (unmineralized) Triassic-Jurassic locations from the Apennines, displaced fragments of the Dinarides, as well as the Dinarides and Hellenides were studied in order to gain representative results. Preliminary SEM-EDS and more detailed EPMA analyses were performed to characterize compositional variations of titanite from basalt, dolerite and gabbro. The obtained results show compositional differences according to the mode of formation. Titanite from VMS mineralized zones shows a composition close to stoichiometric values, and thus can be distinguished based on Ti content ( $\mathrm{Ti}(\mathrm{apfu}) \geq 0.85$ ). Due to $\mathrm{Fe}+\mathrm{Al}$ substitution on Ti site, the $\mathrm{Fe}+\mathrm{Al}$ vs. Ti binary plot seems to be the most discriminant for distinguishing mineralized and unmineralized locations. However, $\mathrm{Fe}$ vs. $\mathrm{Al}, \mathrm{Al}$ vs. Mn and Si vs. $\mathrm{Ca}+\mathrm{Mn}$ discrimination diagrams can also be used. Hence, compositional variations of titanite may be a possible new tool for prospection of concealed Cyprus-type deposits in the Neotethyan realm.
\end{abstract}

Keywords: Cyprus-type deposits; indicator mineral method; submarine magmatic rocks; Neotethyan realm

\section{Introduction}

Titanite (sphene) is a common accessory mineral in igneous and metamorphic rocks as well as in pegmatites and hydrothermal environments [1]. Its compositional variations clearly correlate to the mode of formation (see, e.g., [2-4]); thus this mineral is successfully used as a geothermometer (Zr-in-titanite), as an indicator of sources of detrital material or as an indicator of magmatic crystallization processes $[3,5,6]$. In spite of the obvious possibilities following from these characteristics, titanite is rarely used in exploration geology. Some successful applications are related to Cu-porphyry systems, i.e., the evaluation of porphyry fertile plutons that may be future exploration targets (see, e.g., [7-10]). There is increasing demand for developing new methods of prospection of concealed deposits, particularly in the field of volcanogenic massive sulfide (VMS) deposits [11]. As titanite occurs in rocks of the oceanic crust either as a late stage accessory mineral or as (metasomatic) alteration products [6], it may have the potential to be an indicator mineral of Cyprus-type VMS deposits (Fanerozoic Cu-bearing VMS deposit type, hosted in mafic rocks of the oceanic crust). In the present paper we discuss this possibility and show the results of a still ongoing, comprehensive study carried out in the European Neotethyan realm. 


\section{Background}

\subsection{Basic Mineralogy of Titanite and Its Element Substitutions}

Monoclinic titanite $\left(\mathrm{CaTiSiO}_{5}\right)$ is an orthosilicate, containing independent $\mathrm{Si}-\mathrm{O}$ tetrahedra with groups of $\mathrm{CaO}_{7}$ and $\mathrm{TiO}_{6}$. It may incorporate many elements, which can also have effects on its structure and thus on its unit cell (P21/a may be disordered to A2/a). Rare earth elements (REE), Na, $\mathrm{K}, \mathrm{Mn}, \mathrm{Sr}, \mathrm{Ba}$, Th or Fe may substitute in the Ca site. $\mathrm{Al}, \mathrm{Fe}, \mathrm{Mg}, \mathrm{Nb}, \mathrm{Ta}, \mathrm{V}, \mathrm{Cr}$ or $\mathrm{Zr}$ may substitute in the Ti site. $\mathrm{OH}, \mathrm{F}$ and $\mathrm{Cl}$ substitute for $\mathrm{O}$. $\mathrm{Li}, \mathrm{Sn}, \mathrm{Sb}, \mathrm{Bi}, \mathrm{Pb}, \mathrm{Th}, \mathrm{U}$ and $\mathrm{Sc}$ may be found as rare substituents (see, e.g., $[1,12,13]$ and references cited therein). If Ti substitution occurs, $\mathrm{OH}$ or $\mathrm{F}$ may act as charge balancing anions to replace one $\mathrm{O}$ that is not bonded to $\mathrm{Si}$, especially in the case of pegmatitic, metamorphic or hydrothermal titanite. In the case of magmatic titanite, the coupled substitution of REEs or $Y$ on the Ca site more commonly solves the charge imbalance $[1,4,12]$. The compositional variations clearly correlate to the mode of formation [3]. For example, $\mathrm{Al}$ substitution is favored by high pressure environments [1], though temperature, bulk rock composition, $\mathrm{fH}_{2} \mathrm{O}$ and $\mathrm{fO}_{2}$ as well as the composition of the coexisting fluid also play a role [2]. High-Al titanite is not common in igneous rocks (i.e., high $\mathrm{T}$, low $\mathrm{P}$ conditions), but can form under high $\mathrm{P}$ at any $\mathrm{T}$ and low $\mathrm{T}$ at any $\mathrm{P}$. The absence of anorthite-rich plagioclase—as anorthite elimination release excess $\mathrm{Al}$-also supports its formation [13]. The amount of REEs and Th is affected by the presence of other REE-bearing minerals and the geological environment [12]. A Fe/Al ratio close to 1:1 is typical of igneous titanite, while Fe/Al $<1: 2$ is common in metamorphic titanite. It has also been shown that the Fe/Al ratio of titanite from hydrothermal environments varies greatly, as it crystallizes from fluids characterized by variable compositions [4].

Titanite is a common accessory mineral of igneous rocks, especially in intermediate or acidic plutonic ones. Diorite, syenite and granite are the most common hosts, though it may also occur in more basic rocks as well as in pegmatites. The chemical composition correlates with the host rock: basic-ultrabasic hosts may contain the purest titanite; in syenites this mineral has elevated $\mathrm{Al}, \mathrm{Nb}$ and Fe content, while granites may have titanite with high REE. Metamorphic environments (gneiss, schist and skarns) can also favor titanite formation, as well as some low temperature hydrothermal alteration processes. Titanite is quite rare in sedimentary rocks [12].

Titanite in ore deposits is most commonly related to Cu-porphyry systems (see, e.g., [7-10]), but has also been described in Precambrian VMS deposits [14]. The latter study identified a correlation between the intensity of alteration and the titanite content, as well as local compositional variation (e.g., in Fe, $\mathrm{Zn}$ and Mn content), but did not deal in detail with the applicability of this mineral in mineral exploration. By contrast, the former studies proved the useful application of the compositional variation (especially its $\mathrm{REE}, \mathrm{Y}, \mathrm{U}, \mathrm{Zr}, \mathrm{Th}, \mathrm{Fe}, \mathrm{Al}, \mathrm{Ca}$ and $\mathrm{Sr}$ contents) of titanite in the exploration for Cu-porphyry deposits.

\subsection{Geology of the Studied Samples}

The study areas in the Northern Apennines (Italy), the displaced fragments of the Dinarides (the NE Hungarian Darnó- and Szarvaskő Units are geologically correlated with the Dinarides; their current position is a result of a $\sim 300 \mathrm{~km}$ Cenozoic displacement along the Zagorje-Mid-Transdanubian Zone (see, e.g., [15] and the references cited therein)) (NE Hungary), the Dinarides (Croatia, Albania) and the Hellenides (Greece) represent the Triassic rifting-related submarine environment as well as the Jurassic oceanic crust of the Neotethys (see, e.g., [15-18] and the references cited therein). Each study locality (Figure 1) comprises basalt, dolerite or gabbro, and can be characterized with similar primary (submarine) alteration features and negligible metamorphic overprinting [18-20]. Cu-Zn-Fe-rich Cyprus-type Jurassic VMS deposits were found at the Italian and Albanian ophiolitic locations, comprising massive sulfide lenses or underlying stockwork alteration zones [21,22]. The host rocks are mid-oceanic ridge (MOR)- or suprasubduction zone (SSZ)-type mafic magmatic rocks (see, e.g., [21,23] and the references cited therein). By contrast, barren Triassic and Jurassic submarine within-plate 
basalt (WPB), MOR- or back-arc-basin (BAB)/island arc (IAB)-type magmatic rocks can be found at the other study locations (see, e.g., $[17,18]$ ) (for a brief geological description of each study locality, see Table 1).

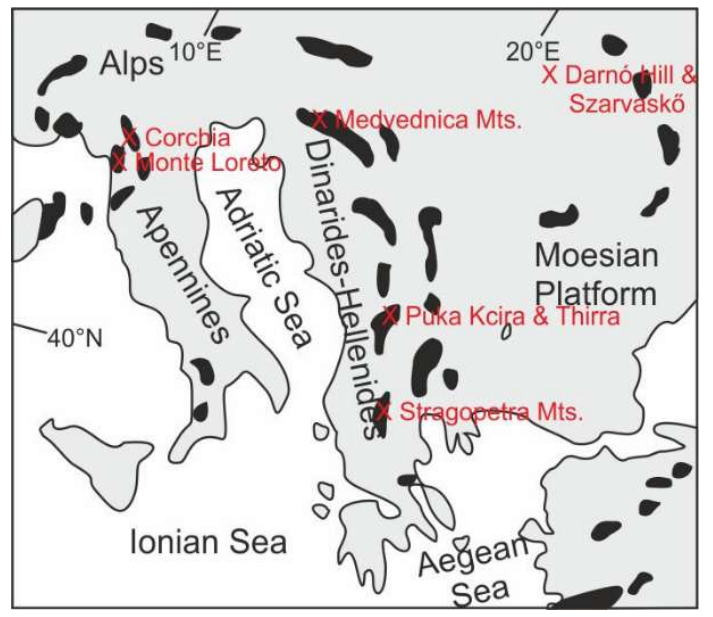

Figure 1. Schematic map showing the Neotethyan ophiolites (black patches) as well as the approximate position of the study locations (red labels) (based on [24]).

Table 1. The locations involved in this study.

\begin{tabular}{|c|c|c|c|c|}
\hline Study Area & Location & Age & Rock Type & $\begin{array}{c}\text { Volcanogenic } \\
\text { Massive Sulfide } \\
\text { Mineralization }\end{array}$ \\
\hline \multirow{4}{*}{$\begin{array}{l}\text { Displaced fragments } \\
\text { of the Dinarides } \\
\text { (Hungary) }\end{array}$} & $\begin{array}{c}\text { Darnó Hill, } \\
\text { Nagy-Rézoldal Quarry }\end{array}$ & Triassic & $\begin{array}{l}\text { Pillow basalt } \\
\text { (WPB) }\end{array}$ & Barren \\
\hline & $\begin{array}{l}\text { Darnó Hill, Mély } \\
\text { Valley Quarry }\end{array}$ & Triassic & $\begin{array}{l}\text { Pillow basalt } \\
\text { (WPB) }\end{array}$ & Barren \\
\hline & $\begin{array}{l}\text { Szarvaskő, Kétvíz } \\
\text { Hill SE }\end{array}$ & Jurassic & $\begin{array}{c}\text { Pillow basalt, } \\
\text { dolerite (BAB/IAB) }\end{array}$ & Barren \\
\hline & $\begin{array}{l}\text { Szarvaskő, Tardos } \\
\text { Quarry }\end{array}$ & Jurassic & Gabbro (BAB/IAB) & Barren \\
\hline \multirow{6}{*}{$\begin{array}{c}\text { Dinarides-Hellenides } \\
\text { (Croatia, Albania, } \\
\text { Greece) }\end{array}$} & Medvednica Mts. S & Triassic & $\begin{array}{l}\text { Pillow basalt } \\
\text { (WPB) }\end{array}$ & Barren \\
\hline & Stragopetra Mts. W & Triassic & $\begin{array}{l}\text { Pillow basalt } \\
\text { (WPB) }\end{array}$ & Barren \\
\hline & Stragopetra Mts S & Triassic & $\begin{array}{l}\text { Pillow basalt } \\
\text { (WPB) }\end{array}$ & Barren \\
\hline & Stragopetra Mts. SW & Triassic & $\begin{array}{l}\text { Pillow basalt } \\
\text { (WPB) }\end{array}$ & Barren \\
\hline & Thirra & Jurassic & Gabbro (SSZ) & Stockwork \\
\hline & Puka-Kcira & Jurassic & Gabbro (MOR) & Stockwork \\
\hline \multirow{2}{*}{ Apennines (Italy) } & Corchia & Jurassic & $\begin{array}{l}\text { Pillow basalt } \\
\text { (MOR) }\end{array}$ & Massive sulfide \\
\hline & Monte Loreto & Jurassic & $\begin{array}{l}\text { Pillow basalt } \\
\text { (MOR) }\end{array}$ & Stockwork \\
\hline
\end{tabular}

\section{Materials and Methods}

Samples from four Cyprus-type VMS deposit-bearing (mineralized) and eight barren (unmineralized) locations were studied in details (Table 1). Detailed field work and petrographical analyses were used to choose the representative, titanite-bearing polished thin and block sections for further analyses. 
Preliminary scanning electron microscopy-energy dispersive spectroscopy (SEM-EDS) and more detailed electron probe microanalyses (EPMA) were used to characterize the compositional variation of titanite from the different locations $(\mathrm{n}=149)$. The SEM-EDS study was carried out at the Department of Petrology and Geochemistry, Eötvös Loránd University (Budapest, Hungary), using an Amray 1830I type microscope equipped with an EDS detector. An accelerating voltage of $20 \mathrm{kV}$ and a counting time of $100 \mathrm{~s}$ were used. The instrument was calibrated with the help of natural standards and the detection limits were $0.1 \%$ for the analyzed major elements. The EPMA study was undertaken at the Eugen Stumpfl Laboratory of the University Center of Applied Geosciences (University of Leoben, Austria), where a Superprobe Jeol JXA 8200 instrument was used in wavelength dispersive spectroscopy (WDS) mode, with $15 \mathrm{kV}$ accelerating voltage and $10 \mathrm{nA}$ beam current. The beam diameter was about $1 \mu \mathrm{m}$. The counting time was $20 \mathrm{~s}$ on peaks and $10-10 \mathrm{~s}$ on backgrounds. The following diffracting crystals were selected: pentaerythritol (PETJ) for $\mathrm{Si}$ and $\mathrm{Ca}$; thallium acid phthalate (TAP) for $\mathrm{Al}$; layered dispersive element (LDE1) for F; and lithium fluoride (LIFH) for Fe, Ti, Cu, Mn and Zn. Synthetic and natural corundum, fluorite, quartz, wollastonite, olivine, rutile, chalcopyrite, rhodonite and sphalerite were used as standards. The detection limits were as follows: 100 ppm for Al, 200 ppm for Ti and Fe, 240 ppm for $\mathrm{Ca}, 300$ ppm for $\mathrm{Si}, 400 \mathrm{ppm}$ for $\mathrm{F}$ and $700 \mathrm{ppm}$ for $\mathrm{Mn}, \mathrm{Cu}$ and $\mathrm{Zn}$.

Analyses data were handled in MS Excel, in which recalculation of mineral formulas, correlation analyses and preparation of several different diagrams as well as representative tables were performed.

\section{Results}

Based on field observations as well as petrographical microscopy, the host rocks of mineralized and unmineralized locations were characterized. Basalt often displays a pillow structure and the primary alteration is very similar at each study locations. Spilitisation is a common feature, as well as the occurrence of hydrothermal minerals (e.g., quartz, calcite, chlorite, epidote, smectites, zeolites); in cooling cracks, amygdales and hyaloclastite breccia are typical. Chloritization, Na-enrichment of plagioclase also occur in the studied dolerite and gabbro, as well as hydrothermal mineral filled veinlets (e.g., quartz, calcite, prehnite, epidote, chlorite). Commonly, alteration is stronger in the mineralized zones, though really intense hydrothermal overprinting (hiding the original rock texture) occurs only in the immediate vicinity of the stockwork veins and massive sulfide lenses. Pyrite, chalcopyrite, pyrrhotite and sphalerite are common ore minerals in the studied Cyprus-type VMS occurrences. In addition, arsenopyrite, cobaltite and rare $\mathrm{Ni}$ - and $\mathrm{Au}$-Ag-tellurides occur in the studied Albanian sites, while galena and rare $\mathrm{Pb}$-selenide, native $\mathrm{Au}$, freibergite and millerite occur in the studied Italian locations (for details, see [19,20,22]).

In each studied rock type (basalt, gabbro, dolerite), titanite occurs in similar textural positions. It may be found either as disseminated anhedral to euhedral grains in the groundmass, or as alteration product of former magmatic minerals. It is also observed in hydrothermal mineral formed crystal aggregates as well as veins and cavities (Figure 2A-C). The grain sizes are in a large range, though they are similar in the mineralized and in the unmineralized zones and in each rock type (commonly from $<10 \mu \mathrm{m}$ to $0.5 \mathrm{~mm}$ ). However, in general, a slightly higher amount of titanite occurs in the mineralized zones. Based on SEM observations, compositional inhomogeneity or zonation was not observed in the studied grains (Figure 2B).

Mineral chemical analyses revealed that titanite had close to stoichiometric Si and Ca values, and substitution in the Ti site was also subordinate. However, besides common Fe and Al contents, some F, Mn, $\mathrm{Cu}$ and $\mathrm{Zn}$ contents were also measured. Obvious differences among $\mathrm{Ti}, \mathrm{Al}, \mathrm{Fe}, \mathrm{F}$ and $\mathrm{Mn}$ contents of titanite from mineralized and unmineralized zones could be observed. Slight enrichment in $\mathrm{Ti}$ and depletion in $\mathrm{Al}, \mathrm{Fe}, \mathrm{Mn}$ and $\mathrm{F}$ contents was observable in titanite from mineralized zones (Figure 3). By contrast, no significant differences were observable according to different rock types or ages (for details, see Table 2 and Appendices A and B). 

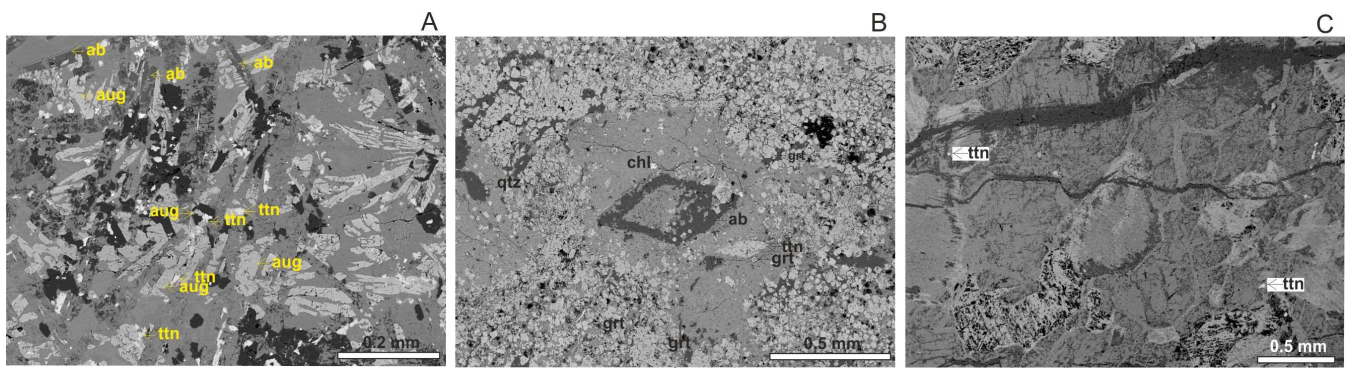

Figure 2. Typical textural features of titanite at the studied locations. (A): Disseminated, fine grained anhedral titanite in basalt (Nagy-Rézoldal Quarry, BSE image). (B): Coarse grained, euhedral titanite in hydrothermal mineral formed crystal aggregate in strongly altered basalt (Kétvíz Hill SE, BSE image). (C): Disseminated, fine grained anhedral titanite in altered gabbro (Thirra, BSE image by courtesy of A. Lovász). Abbreviations: ab—albite; aug—augite; chl—chlorite; grt—garnet; th—-titanite.

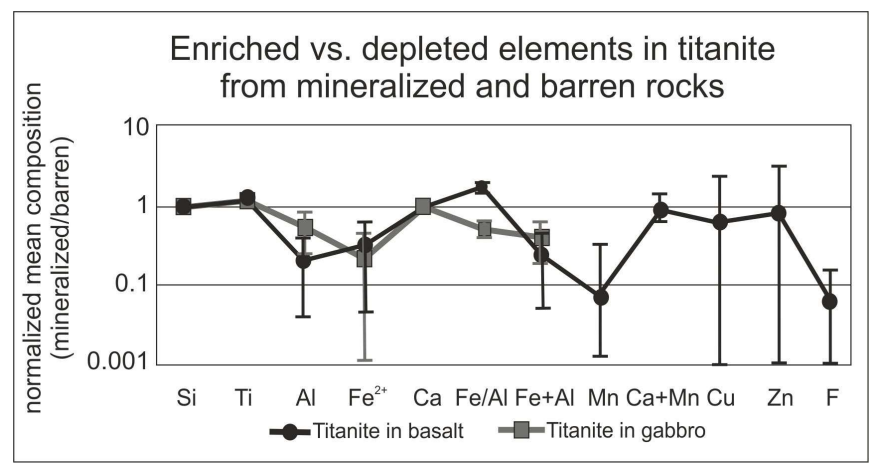

Figure 3. Titanite from mineralized zones shows enrichment in Ti content as well as a slightly higher $\mathrm{Fe} / \mathrm{Al}$ ratio and depletion in $\mathrm{Al}, \mathrm{Fe}, \mathrm{Mn}, \mathrm{F}, \mathrm{Cu}$ and $\mathrm{Zn}$ contents compared to unmineralized zones.

Table 2. Recalculation of titanite formula, using a fixed number of five oxygens.

\begin{tabular}{|c|c|c|c|c|c|}
\hline & & \multicolumn{2}{|c|}{$\begin{array}{l}\text { Titanite from Unmineralized } \\
\text { Zones }(n=75)\end{array}$} & \multicolumn{2}{|c|}{$\begin{array}{c}\text { Titanite from Mineralized } \\
\text { Zones }(\mathrm{n}=74)\end{array}$} \\
\hline & & basalt & dolerite-gabbro & basalt & gabbro \\
\hline \multirow{4}{*}{$\mathrm{Si}$} & mean & 1.063 & 1.055 & 1.038 & 1.035 \\
\hline & $\min$ & 1.000 & 1.030 & 1.006 & 1.020 \\
\hline & $\max$ & 1.130 & 1.100 & 1.063 & 1.068 \\
\hline & st.dev. & 0.023 & 0.031 & 0.014 & 0.016 \\
\hline \multirow{4}{*}{$\mathrm{Ti}$} & mean & 0.775 & 0.793 & 0.944 & 0.913 \\
\hline & $\min$ & 0.680 & 0.740 & 0.854 & 0.866 \\
\hline & $\max$ & 0.840 & 0.840 & 0.983 & 0.943 \\
\hline & st.dev. & 0.033 & 0.043 & 0.034 & 0.025 \\
\hline \multirow{4}{*}{ Al } & mean & 0.179 & 0.138 & 0.038 & 0.072 \\
\hline & $\min$ & 0.124 & 0.110 & 0.006 & 0.047 \\
\hline & $\max$ & 0.260 & 0.170 & 0.093 & 0.120 \\
\hline & st.dev. & 0.037 & 0.028 & 0.023 & 0.023 \\
\hline \multirow{4}{*}{$\mathrm{Fe}^{2+}$} & mean & 0.072 & 0.110 & 0.023 & 0.024 \\
\hline & $\min$ & 0.030 & 0.050 & 0.003 & 0.010 \\
\hline & $\max$ & 0.130 & 0.180 & 0.063 & 0.043 \\
\hline & st.dev. & 0.021 & 0.054 & 0.013 & 0.011 \\
\hline \multirow{4}{*}{ Mn } & mean & 0.012 & $\mathrm{n} / \mathrm{a}$ & 0.001 & 0.002 \\
\hline & $\min$ & b.d.l. & $\mathrm{n} / \mathrm{a}$ & b.d.l. & b.d.l. \\
\hline & $\max$ & 0.029 & $\mathrm{n} / \mathrm{a}$ & 0.006 & 0.006 \\
\hline & st.dev. & 0.009 & $\mathrm{n} / \mathrm{a}$ & 0.002 & 0.002 \\
\hline
\end{tabular}


Table 2. Cont.

\begin{tabular}{|c|c|c|c|c|c|}
\hline & & \multicolumn{2}{|c|}{$\begin{array}{l}\text { Titanite from Unmineralized } \\
\text { Zones }(\mathrm{n}=75)\end{array}$} & \multicolumn{2}{|c|}{$\begin{array}{c}\text { Titanite from Mineralized } \\
\text { Zones }(\mathrm{n}=74)\end{array}$} \\
\hline & & basalt & dolerite-gabbro & basalt & gabbro \\
\hline \multirow{4}{*}{$\mathrm{Ca}$} & mean & 0.969 & 0.983 & 0.956 & 0.968 \\
\hline & $\min$ & 0.880 & 0.890 & 0.923 & 0.934 \\
\hline & $\max$ & 1.030 & 1.020 & 0.980 & 0.979 \\
\hline & st.dev. & 0.020 & 0.062 & 0.013 & 0.014 \\
\hline \multirow{4}{*}{$\mathrm{Cu}$} & mean & 0.002 & $\mathrm{n} / \mathrm{a}$ & 0.001 & 0.002 \\
\hline & $\min$ & b.d.l. & $\mathrm{n} / \mathrm{a}$ & b.d.l. & b.d.l. \\
\hline & $\max$ & 0.009 & $\mathrm{n} / \mathrm{a}$ & 0.006 & 0.004 \\
\hline & st.dev. & 0.003 & $\mathrm{n} / \mathrm{a}$ & 0.002 & 0.002 \\
\hline \multirow{4}{*}{ Zn } & mean & 0.001 & $\mathrm{n} / \mathrm{a}$ & 0.001 & 0.001 \\
\hline & $\min$ & b.d.l. & $\mathrm{n} / \mathrm{a}$ & b.d.l. & b.d.l. \\
\hline & $\max$ & 0.006 & $\mathrm{n} / \mathrm{a}$ & 0.005 & 0.005 \\
\hline & st.dev. & 0.002 & $\mathrm{n} / \mathrm{a}$ & 0.001 & 0.002 \\
\hline \multirow{4}{*}{$\mathrm{Fe} / \mathrm{Al}$} & mean & 0.413 & 0.786 & 0.663 & 0.380 \\
\hline & $\min$ & 0.143 & 0.417 & 0.321 & 0.118 \\
\hline & $\max$ & 0.740 & 1.059 & 1.861 & 0.693 \\
\hline & st.dev. & 0.046 & 0.076 & 0.036 & 0.021 \\
\hline \multirow{4}{*}{$\begin{array}{c}\mathrm{Fe}+ \\
\mathrm{Al}\end{array}$} & mean & 0.251 & 0.248 & 0.060 & 0.096 \\
\hline & $\min$ & 0.187 & 0.170 & 0.010 & 0.064 \\
\hline & $\max$ & 0.380 & 0.350 & 0.147 & 0.139 \\
\hline & st.dev. & 0.046 & 0.076 & 0.036 & 0.021 \\
\hline \multirow{4}{*}{$\begin{array}{l}\mathrm{Ca}+ \\
\mathrm{Mn}\end{array}$} & mean & 0.980 & $\mathrm{n} / \mathrm{a}$ & 0.957 & 0.970 \\
\hline & $\min$ & 0.880 & $\mathrm{n} / \mathrm{a}$ & 0.923 & 0.934 \\
\hline & $\max$ & 1.030 & $\mathrm{n} / \mathrm{a}$ & 0.982 & 0.985 \\
\hline & st.dev. & 0.335 & $\mathrm{n} / \mathrm{a}$ & 0.013 & 0.011 \\
\hline \multirow{4}{*}{$\mathbf{F}$} & mean & 1.318 & $\mathrm{n} / \mathrm{a}$ & 0.101 & $\mathrm{n} / \mathrm{a}$ \\
\hline & $\min$ & b.d.l. & $\mathrm{n} / \mathrm{a}$ & b.d.l. & b.d.l. \\
\hline & $\max$ & 2.175 & $\mathrm{n} / \mathrm{a}$ & 0.223 & b.d.l. \\
\hline & st.dev. & 0.652 & $\mathrm{n} / \mathrm{a}$ & 0.053 & $\mathrm{n} / \mathrm{a}$ \\
\hline
\end{tabular}

Results are given in apfu, except for F (wt\%); st.dev.: standard deviation; n/a: not available; b.d.l.: below detection limit.

\section{Discussion}

\subsection{Element Substitution on the Ti Site}

As expected from [12], the analyzed titanite grains showed a chemical composition close to stoichiometric values. The measured average $\mathrm{Ti}, \mathrm{Fe}$ and $\mathrm{Al}$ amounts were consistent with the observations of [25], i.e., there is no need to assign any $\mathrm{Al}$ to the tetrahedral (Si) site. High Al-content (up to $5.365 \mathrm{wt} \% \mathrm{Al}_{2} \mathrm{O}_{3}$ ) was consistent with the formation conditions, i.e., relatively low temperature and absence of anorthite-rich plagioclase [13]. Similarly to the hydrothermal titanite results of [4], $\mathrm{Fe} / \mathrm{Al}$ ratios scattered widely and consistent variability was not observed. High FeO content (up to $5 \mathrm{wt} \%$ ) observed in the mafic rocks of Precambrian Noranda [14] was not found in these young Neotethyan rocks. The highest values were measured from a Hungarian unmineralized occurrence (up to $\mathrm{FeO}=3.778 \mathrm{wt} \%$ ).

The most important $\mathrm{Ti}$ site substitutions were $\mathrm{Fe}+\mathrm{Al}$ both in the mineralized and unmineralized zones, which is proven by the observable strong negative correlation $(r=-0.929)$. There was, however, a distinct difference between the degrees of substitution. Values closer to stoichiometric titanite (i.e., $\mathrm{Ti}(\mathrm{apfu})=0.85-1)$ was characteristic to mineralized zones, while unmineralized zones contained titanite with higher amount of substitution (i.e., Ti (apfu) $=0.7-0.85)$ (Figure 4). 


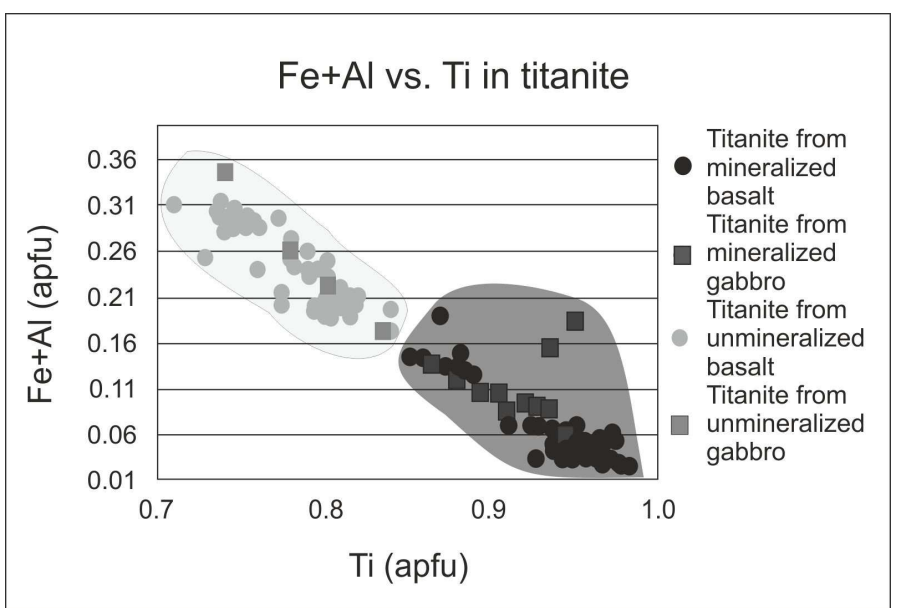

Figure 4. $\mathrm{Fe}+\mathrm{Al}$ vs. Ti content of titanite from mineralized and unmineralized zones. Distinct fields can be assigned: titanite from mineralized rocks is characterized by $\mathrm{Ti}>0.85$ and $\mathrm{Fe}+\mathrm{Al}<0.18$ (apfu).

Al content was commonly higher, while Fe content was overlapping or higher in unmineralized zones (Table 2). Interestingly, while there was a rather strong correlation between $\mathrm{Fe}$ and $\mathrm{Al}$ in mineralized zones $(r=0.697)$, their relation was independent in unmineralized zones $(r=0.097)$. Consequently, $\mathrm{Ti}$ and $\mathrm{Al}$ showed a strong negative correlation in each titanite type $(\mathrm{r}=-0.898$ and $\mathrm{r}=-0.805$, respectively, see Appendices A and B), while the relation of Ti and Fe was strong only in the case of mineralized zones $(r=-0.788)$ and much weaker in unmineralized ones $(r=-0.472)$ (see Appendices A and B). This fact may draw attention to the possibility of excess Fe substitution in Ca sites [12] in unmineralized zones. As a conclusion, on the Ti vs. Fe $+\mathrm{Al}$ and $\mathrm{Al}$ vs. Fe diagram, different fields can be assigned clearly for titanite compositions from mineralized and unmineralized zones (Figures 4 and 5).

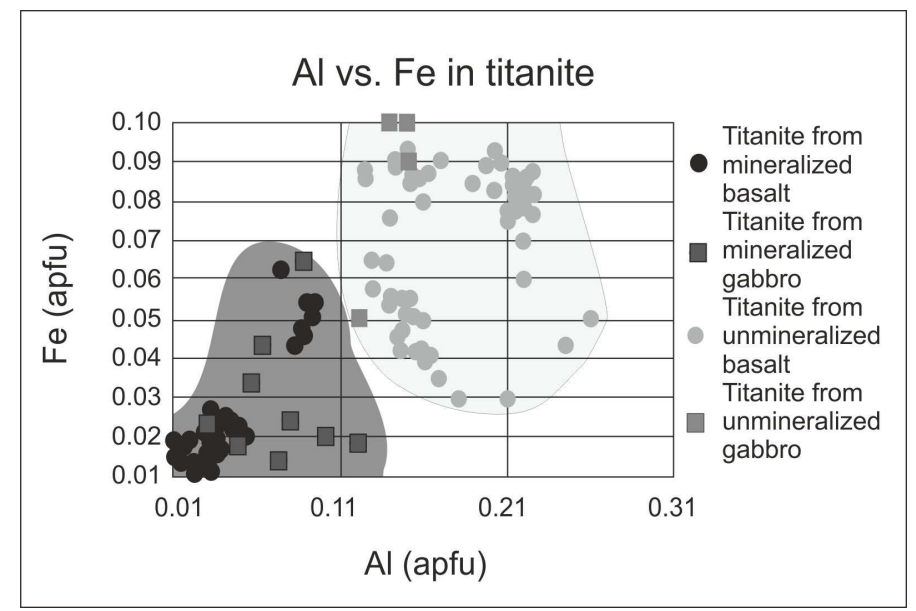

Figure 5. Al vs. Fe content of titanite from mineralized and unmineralized zones. Distinctly different fields can be assigned.

To summarize, titanite from mineralized and unmineralized zones could be rather trustworthily distinguished based on Ti site substitutions.

\subsection{Charge Balancing}

Based on the literature $[1,4,12]$, charge balance in hydrothermal titanite due to $\mathrm{Fe}^{2+} \beta^{3+}$ and $\mathrm{Al}^{3+}$ substitution into the $\mathrm{Ti}^{4+}$ site is largely accomplished by the coupled substitution of $\mathrm{F}^{-}$for $\mathrm{O}^{2-}$. In the case of unmineralized zone titanites, where the substitution into the Ti site is characteristically higher, 
a clear correlation $(\mathrm{r}=0.972)$ has been seen between $\mathrm{Fe}+\mathrm{Al}$ and $\mathrm{F}$ as well as between $\mathrm{Ti}$ and $\mathrm{F}$ $(\mathrm{r}=-0.811)$ (see Appendices A and B). These facts support the above findings.

\subsection{Element Substitutions on the Ca Site}

In the studied geological environment, $\mathrm{Mn}$ is the most probable Ca site substitution. However, according to our results, it is not particularly enriched in titanite from mineralized zones (Table 2). Such high amounts reported by [14] from the Noranda VMS deposit (up to $0.2 \mathrm{wt} \% \mathrm{MnO}$ ) were not observed; moreover it is commonly below detection limit in the studied mineralized Neotethyan samples. By contrast, rather high Mn content can be observed in titanite from unmineralized zones (up to $1 \mathrm{wt} \% \mathrm{MnO}$ ). Consequently, weak positive correlation between $\mathrm{Ca}$ and $\mathrm{Mn}$ content is observable only in the latter case $(\mathrm{r}=0.540)$.

On the Mn vs. Ca diagram, exact fields for titanite from mineralized and unmineralized zones cannot be assigned. However, on the Al vs. Mn and Si vs. Ca+Mn diagrams-despite some overlapping in the latter case-we may be able to distinguish titanite grains of different origin (Figures 6 and 7).

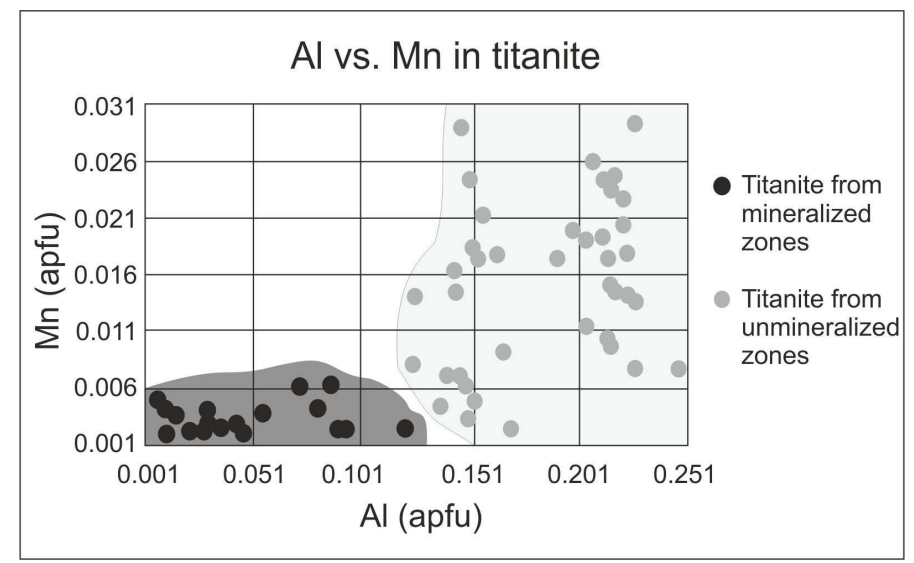

Figure 6. Al vs. Mn content of titanite from mineralized and unmineralized zones. Different fields can be clearly assigned.

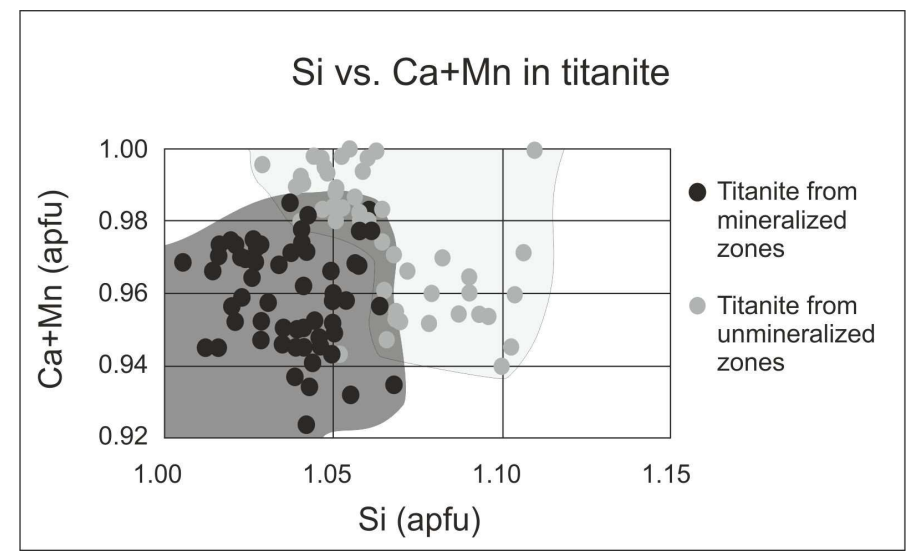

Figure 7. Si vs. $\mathrm{Ca}+\mathrm{Mn}$ content of titanite from mineralized and unmineralized zones. Different fields—albeit with some overlapping — can be assigned.

As suggested earlier, we may assume some $\mathrm{Fe}^{2+}$ substitution in the Ca site in the case of titanite from unmineralized zones. This may explain the strong correlation between Fe and $\mathrm{Mn}(\mathrm{r}=0.785)$ in these titanite grains (see Appendix B). 


\subsection{Metal Substitutions}

Hannington et al. [14] observed up to $0.14 \mathrm{wt} \% \mathrm{ZnO}$ substitution in titanite from the Noranda VMS deposit. In most cases, our data scatter in a similar range, though a maximum of $0.236 \mathrm{wt} \%$ $\mathrm{ZnO}$ content was found. $\mathrm{CuO}$ content also scattered in a similar range, with a maximum of 0.368 $w t \%$. However, there was no characteristic difference between $\mathrm{Zn}$ and $\mathrm{Cu}$ content of titanite from mineralized and unmineralized locations, though the highest $\mathrm{Zn}$ and $\mathrm{Cu}$ values were measured from the latter occurrences. As the development of a hydrothermal fluid circulation system leaches the metals (e.g., $\mathrm{Cu}, \mathrm{Zn}, \mathrm{Mn}$ ) from the silicates [26], occasionally high metal content of titanite from unmineralized zone may be due to the lack of extensive alteration.

\section{Concluding Remarks}

In the present study, Neotethyan mafic igneous rocks from Cyprus-type VMS mineralizations and barren locations were studied. The submarine rocks show similar primary alteration features, and therefore it is hard to localize the concealed, economically potential (i.e., locally mineralized and strongly altered) occurrences. The research presented here, however, revealed some conclusions regarding the possible use of titanite chemistry for modern Cyprus-type VMS deposit prospecting in the Neotethyan realm. This mineral occurs in each possible host rock types and its compositional variations correlate well with the mode of formation. The following distinguishing features can be listed:

- Titanite closer to stoichiometric composition ( $\mathrm{Ti}(\mathrm{apfu}) \geq 0.85)$ is found in mineralized zones, while $\mathrm{Ti}(\mathrm{apfu}) \leq 0.85$ characterizes titanite from unmineralized zones.

- A Fe+Al vs. Ti binary plot seems to be the most discriminant for distinguishing titanite from mineralized and unmineralized locations.

- On Al vs. Fe as well as Al vs. Mn diagrams, different fields can be assigned clearly for titanite compositions from mineralized and unmineralized zones.

- On a Si vs. Ca+Mn diagram—despite some overlapping—we may also be able to distinguish titanite grains of mineralized and unmineralized zone origins.

- The possibility of excess Fe substitution in Ca site occurs only in titanite from unmineralized zones.

- Higher Mn, F and occasionaly $\mathrm{Zn}, \mathrm{Cu}$ contents are characteristic in titanite from unmineralized zones.

The study locations cover a wide geographic area, though all of them represent the same geotectonic situation, i.e., the rifting and spreading of the Neotethys. Therefore the above conclusions have to be handled accordingly and further research should be performed. Future research should involve not only a detailed mineral chemical study of more locations, but also more complimentary geostatistical investigations to better evaluate the use of titanite chemistry in mineral exploration.

Author Contributions: Conceptualization, investigation, methodology, analyses, visualization, writing (original draft preparation) and supervision, G.B.K.; analyses, writing (review), methodology, F.Z. All authors have read and agreed to the published version of the manuscript.

Funding: This research was supported by the Hungarian National Science Fund OTKA PD 112580 (to G.B.K.) by NKFIH (National Research, Development and Innovation Office).

Acknowledgments: The authors are thankful to I. Barna, G. Garuti, A. Lovász, A. Lukács, Zs. Molnár, D. Pásztor and P. Skoda for providing some of the analyzed samples. Zs. Bendő is thanked for assistance during SEM-EDS analyses. I. Dódony is thanked for the discussions on the mineralogy of titanite. S. Strmic-Palinkas is thanked for useful comments while finalizing this manuscript. The comments of two anonymous reviewers have contributed greatly to the improvement of the original manuscript. The Eugen F. Stumpfl Electron Microprobe Laboratory (University of Leoben) is thanked for the access to the EPMA laboratory.

Conflicts of Interest: The authors declare no conflict of interest. 


\section{Appendix A}

Table A1. Correlation matrix of titanite compositions from mineralized zones.

\begin{tabular}{|c|c|c|c|c|c|c|c|c|c|c|c|c|}
\hline & Si & Ti & Al & $\mathrm{Fe}^{+2}$ & Mn & $\mathrm{Ca}$ & $\mathrm{Cu}$ & $\mathrm{Zn}$ & $\mathrm{Fe} / \mathrm{Al}$ & $\mathrm{Fe}+\mathrm{Al}$ & $\mathrm{Ca}+\mathrm{Mn}$ & $\mathbf{F}$ \\
\hline $\mathrm{Si}$ & 1 & & & & & & & & & & & \\
\hline Ti & -0.535 & 1 & & & & & & & & & & \\
\hline Al & 0.156 & -0.898 & 1 & & & & & & & & & \\
\hline $\mathrm{Fe}^{+2}$ & 0.323 & -0.788 & 0.697 & 1 & & & & & & & & \\
\hline Mn & 0.119 & -0.176 & 0.146 & 0.026 & 1 & & & & & & & \\
\hline $\mathrm{Ca}$ & -0.190 & -0.541 & 0.620 & 0.347 & 0.064 & 1 & & & & & & \\
\hline $\mathrm{Cu}$ & 0.105 & -0.244 & 0.204 & 0.157 & 0.112 & 0.178 & 1 & & & & & \\
\hline $\mathrm{Zn}$ & 0.042 & -0.053 & 0.078 & -0.040 & -0.202 & -0.045 & -0.121 & 1 & & & & \\
\hline $\mathrm{Fe} / \mathrm{Al}$ & 0.138 & 0.284 & -0.466 & 0.060 & 0.072 & -0.429 & 0.021 & -0.199 & 1 & & & \\
\hline $\mathrm{Fe}+\mathrm{Al}$ & 0.228 & -0.926 & 0.966 & 0.858 & 0.114 & 0.568 & 0.202 & 0.041 & -0.312 & 1 & & \\
\hline $\mathrm{Ca}+\mathrm{Mn}$ & -0.173 & -0.554 & 0.628 & 0.345 & 0.183 & 0.993 & 0.189 & -0.069 & -0.414 & 0.573 & 1 & \\
\hline F & 0.592 & -0.702 & 0.653 & 0.534 & 0.208 & 0.570 & 0.437 & -0.075 & -0.248 & 0.620 & 0.565 & 1 \\
\hline
\end{tabular}

\section{Appendix B}

Table A2. Correlation matrix of titanite compositions from unmineralized zones.

\begin{tabular}{|c|c|c|c|c|c|c|c|c|c|c|c|c|}
\hline & $\mathrm{Si}$ & $\mathrm{Ti}$ & $\mathrm{Al}$ & $\mathrm{Fe}^{+2}$ & Mn & $\mathrm{Ca}$ & $\mathrm{Cu}$ & $\mathrm{Zn}$ & $\mathrm{Fe} / \mathrm{Al}$ & $\mathrm{Fe}+\mathrm{Al}$ & $\mathrm{Ca}+\mathrm{Mn}$ & F \\
\hline $\mathrm{Si}$ & 1 & & & & & & & & & & & \\
\hline $\mathrm{Ti}$ & -0.203 & 1 & & & & & & & & & & \\
\hline $\mathrm{Al}$ & -0.122 & -0.806 & 1 & & & & & & & & & \\
\hline $\mathrm{Fe}^{+2}$ & -0.087 & -0.472 & 0.097 & 1 & & & & & & & & \\
\hline Mn & -0.516 & -0.594 & 0.471 & 0.785 & 1 & & & & & & & \\
\hline $\mathrm{Ca}$ & -0.667 & 0.073 & -0.058 & 0.049 & 0.540 & 1 & & & & & & \\
\hline $\mathrm{Cu}$ & -0.090 & 0.132 & -0.085 & -0.049 & -0.081 & -0.068 & 1 & & & & & \\
\hline $\mathrm{Zn}$ & -0.212 & -0.031 & 0.127 & 0.008 & 0.013 & 0.082 & 0.023 & 1 & & & & \\
\hline $\mathrm{Fe} / \mathrm{Al}$ & -0.032 & 0.024 & -0.456 & 0.817 & 0.401 & 0.108 & 0.039 & -0.082 & 1 & & & \\
\hline $\mathrm{Fe}+\mathrm{Al}$ & -0.144 & -0.893 & 0.849 & 0.608 & 0.710 & -0.020 & -0.088 & 0.104 & 0.069 & 1 & & \\
\hline $\mathrm{Ca}+\mathrm{Mn}$ & -0.717 & -0.058 & 0.053 & 0.170 & 0.819 & 0.940 & -0.083 & 0.061 & 0.146 & 0.132 & 1 & \\
\hline F & -0.724 & -0.811 & 0.882 & 0.658 & 0.726 & 0.749 & -0.009 & 0.062 & 0.009 & 0.972 & 0.841 & 1 \\
\hline
\end{tabular}

\section{References}

1. Gaines, R.V.; Skinner, H.C.W.; Foord, E.E.; Mason, B.; Rosenzweig, A.; King, V.T.; Dowty, E. The System of Mineralogy of James Dwight Dana and Edward Salisbury Dana, 8th ed.; John Wiley \& Sons Inc.: New York, NY, USA, 1997; p. 1819.

2. Harlov, D.; Tropper, P.; Seifert, W.; Nijland, T.; Förster, H.-J. Formation of Al-rich titanite (CaTiSiO4O-CaAlSiO4OH) reaction rims on ilmenite in metamorphic rocks as a function of $\mathrm{fH} 2 \mathrm{O}$ and $\mathrm{fO} 2$. Lithos 2006, 88, 72-84. [CrossRef]

3. Kowallis, B.J.; Christiansen, E.H.; Griffen, D.T. Compositional Variations in Titanite; Abstracts with Programs; Geological Society of America: Boulder, CO, USA, 1997; Volume 29, p. A-402.

4. Kowallis, B.J.; Christiansen, E.H.; Dorais, M.J.; Winkel, A.; Henze, P.; Franzen, L.; Webb, H. Compositional variation of $\mathrm{Fe}, \mathrm{Al}$ and $\mathrm{F}$ in Titanite (Sphene); Abstracts with Programs, Paper no. 137-11; Geological Society of America: Boulder, CO, USA, 2018; Volume 50.

5. Hayden, L.A.; Watson, E.B.; Wark, D.A. A thermobarometer for sphene (titanite). Contrib. Mineral. Petrol. 2008, 155, 529-540. [CrossRef]

6. Colwell, L.E.; John, B.E.; Cheadle, M.J.; Wooden, J.L. Chemistry of Titanite (Sphene) in Ocean Crust: A Tool for Understanding Late-Stage Igneous and Metasomatic Processes at Mid-Ocean Ridges; Fall Meeting 2011, abs. id. V11A-2493; American Geophysical Union: Washington, DC, USA, 2011.

7. Bouzari, F.; Hart, C.J.R.; Bissig, T.; Lesage, G. Apatite and Titanite Characteristics of Porphyry Fertile Plutons. In Proceeding of the SEG2019 Conference Proceedings, Santiago, Chile, 7-10 October 2019; p. 041.

8. Matthews, T.J.; Wilkinson, J.J.; Loader, M.A. Titanite Petrology and Chemistry from the Strontian Igneous Complex. In Proceeding of the SEG2019 Conference Proceedings, Santiago, Chile, 7-10 October 2019; p. 121. 
9. Xu, L.; Bi, X.; Hu, R.; Tang, Y.; Wang, X.; Xu, Y. LA-ICP-MS mineral chemistry of titanite and the geological implications for exploration of porphyry $\mathrm{Cu}$ deposits in the Jinshajiang-Red River alkaline igneous belt, SW China. Miner. Petrol. 2015, 109, 181-200. [CrossRef]

10. Pan, L.C.; Hu, R.Z.; Bi, X.W.; Li, C.; Wang, X.S.; Zhu, J.J. Titanite major and trace element compositions as petrogenetic and metallogenic indicators of Mo ore deposits: Examples from four granite plutons in the southern Yidun arc, SW China. Am. Miner. 2018, 103, 1417-1434. [CrossRef]

11. Shanks, W.C.P., III; Thurston, R. (Eds.) Volcanogenic massive sulfide occurrence model. In U.S. Geological Survey Scientific Investigations Report; 2010-5070-C; USGS: Reston, VA, USA, 2012; p. 345.

12. Deer, W.A.; Howie, R.A.; Zussman, J. Rock-Forming Minerals: Orthosilicates, 2nd ed.; Geological Society of London: London, UK, 1982; Volume 1A, pp. 443-466.

13. Oberti, R.; Smith, D.C.; Rossi, G.; Caucia, F. The crystal-chemistry of high-aluminium titanites. Eur. J. Miner. 1991, 3, 777-792. [CrossRef]

14. Hannington, M.D.; Santaguida, F.; Kjarsgaard, I.M.; Cathles, L.M. Regional-scale hydrothermal alteration in the Central Blake River Group, western Abitibi subprovince, Canada: Implications for VMS prospectivity. Miner. Depos. 2003, 38, 393-422. [CrossRef]

15. Pamić, J.; Tomljenović, B.; Balen, D. Geodynamic and petrogenetic evolution of alpine ophiolites from the central and NW Dinarides: An overview. Lithos 2002, 65, 113-142. [CrossRef]

16. Piccardo, G.B.; Rampone, E.; Romairone, A. Formation and composition of the oceanic lithosphere of the Ligurian Tethys: Inferences from the Ligurian ophiolites. Ofioliti 2002, 27, 145-161.

17. Robertson, A.H.F.; Karamata, S.; Šarić, K. Overview of ophiolites and related units in the Late Palaeozoic-Early Cenozoic magmatic and tectonic development of Tethys in the northern part of the Balkan region. Lithos 2009, 108, 1-36. [CrossRef]

18. Kiss, G.; Molnár, F.; Palinkaš, L.A.; Kovács, S.; Hrvatović, H. Correlation of Triassic advanced rifting-related Neotethyan submarine basaltic volcanism of the Darnó Unit (NE-Hungary) with some Dinaridic and Hellenidic occurrences on the basis of volcanological, fluid-rock interaction, and geochemical characteristics. Int. J. Earth Sci. 2012, 101, 1503-1521. [CrossRef]

19. Kiss, G.B.; Molnár, F.; Palinkaš, L.A. Hydrothermal processes related to some Triassic and Jurassic submarine basaltic complexes in northeastern Hungary, the Dinarides and Hellenides. Geol. Croat. 2016, 69, 39-64. [CrossRef]

20. Zaccarini, F.; Garuti, G. Mineralogy and composition of VMS deposits of northern Apennine ophiolites, Italy: Evidence for the influence of country rock type on ore composition. Miner. Petrol 2008, 94, 61. [CrossRef]

21. Garuti, G.; Bartoli, O.; Scacchetti, M.; Zaccarini, F. Geological setting and structural styles of Volcanic Massive Sulfide deposits in the northern Apennines (Italy): Evidence for seafloor and sub-seafloor hydrothermal activity in unconventional ophiolites of the Mesozoic Tethys. Bol. Soc. Geol. Mex. 2008, 60, 121-145. [CrossRef]

22. Lovász, A.; Kiss, G.B.; Czuppon, G.; Benkó, Z. Genetic study of gabbro hosted copper mineralisations in the Albanian Mirdita Zone. In Geologica Balcanica, XXI International Congress of the CBGA; Neubauer, F., Brendel, U., Friedl, G., Eds.; Geologica Balcanica: Sofia, Bulgaria, 2018; p. 307.

23. Doda, V.; Deda, V.; Alliu, I. Sulphide Mineralizations in Gabbro and Plagiogranites in Ophiolites of Albanides. Bul. Shke. Gjeol. 2014, 2, 374-377.

24. Dilek, Y.; Furnes, H.; Shallo, M. Suprasubduction zone ophiolite formation along the periphery of Mesozoic Gondwana. Gondwana Res. 2007, 11, 453-475. [CrossRef]

25. Higgins, J.B.; Ribbe, P.H. The crysta1 chemistry and space groups of natural and synthetic titanites. Am. Min. 1976, 61, 878-888.

26. Seyfried, W.E., Jr.; Mottl, M.J. Hydrothermal alteration of basalt by seawater under seawater-dominated conditions. Geochim. Cosmochim. Acta 1982, 64, 985-1002. [CrossRef]

(C) 2020 by the authors. Licensee MDPI, Basel, Switzerland. This article is an open access article distributed under the terms and conditions of the Creative Commons Attribution (CC BY) license (http://creativecommons.org/licenses/by/4.0/). 